\title{
An examination of imagery used to represent fundamental British values and British identity on primary school display boards
}

\author{
Marlon Moncrieffe* and Audrey Moncrieffe - University of Brighton, UK
}

\begin{abstract}
It is observable that display boards are being applied widely by primary schools as visual representations for teaching and learning about the stated fundamental British values of democracy, the rule of law, individual liberty and the mutual respect and tolerance of those with different faiths and beliefs. The research presented by this article is based upon analysis of 27 display boards from primary schools across England, including findings from in-depth interviews with three primary school teachers. We wanted to identify and to understand how discourses of British national identity such as monoculturalism and multiculturalism are reified by schools and teachers through the imagery used on primary school display boards in the representation of fundamental British values. Our research makes an original contribution to the debate on teaching and learning about national identity, by offering empirical evidence both of representations of fundamental British values and of teacher interpretations of the policy.
\end{abstract}

Keywords: national identity; fundamental British values; monoculturalism; multiculturalism; imagery

\section{Introduction}

Primary schools and their teachers in England and Wales are expected by statute to uphold, actively promote and not undermine the fundamental British values of democracy, the rule of law, individual liberty and the mutual respect and tolerance of those with different faiths and beliefs (DfE, 2011, 2014). However, it is argued that this is a professional duty imposed upon them by policymakers without professional dialogue (Elton-Chalcraft et al., 2017; Lander, 2016). The focus of this research is on primary schools' and teachers' responses to the policies of fundamental British values. The primary school is identified by this research as a site of representation for providing powerful grounds on which dominant political and cultural discourses of national identity can be reified as a regime of truth (Foucault, 1980). We present, examine and critically analyse those choices through theoretical lenses associated with power, national identity construction and representation. Data generated by this research arrives also from professional dialogue with primary school teachers, where they articulate their understanding of fundamental British values and British identity via imagery used on primary school display boards.

Our sense of curiosity about approaches to practice concerning fundamental British values has been heightened over the last four years by our professional visits to a diverse range of primary schools. We began to share our observations that display boards were being used increasingly to represent fundamental British values since 
the introduction of the DfE (2014) policy. It was a British values primary school display board based on white British artist Grayson Perry's 'Who are You?' (Higgins, 2014) that increased our interest and motivation to conduct this research. That primary school display board represented fundamental British values and British identity through images of Queen Elizabeth II, the red Routemaster London bus, a cup of tea, Winston Churchill, William Shakespeare, John Lewis (a department store) and a bulldog. We noticed the overpoweringly white British imagery and considered that dominant monocultural representation of Britishness and British values as being problematic in a continuously developing twenty-first-century multicultural British society. It made us curious to know more about the power of the school display board as a tool for promoting discourses visually to enable the reification of political agendas for education (Foucault, 1972). We conceived the view that an examination of the imagery used on primary school display boards depicting fundamental British values as British identity would help to bring to greater attention the images most frequently used and any group of images that was more dominant than another. From this approach to our thinking emerged the first key aim of the research: what are the most frequently used images on primary school display boards that denote fundamental British values when British identity is represented?

We were interested in the implicit nature of the images, by their representations of fundamental British values and British identity, and where they could arguably be positioned (whether with or against) in terms of contested concepts around teaching and learning about nationalism and British identity, that is monoculturalism and multiculturalism (Race, 2015). We also perceived that engaging in professional dialogue with primary school teachers, to gain their perspectives on fundamental British values as represented by images on display boards, could offer some understanding of the nature of British identity that is being promoted by primary schools. It was an approach to our thinking which related to the second key aim of the research: which images do teachers interpret as being most and least representative of fundamental British values when British identity is represented?

This research situates itself with the works of Osler (2008), Crick (2008) and Starkey (2008), all of whom examined the role of education in promoting national identity and citizenship. Although it has been ten years since their arguments and comments were shared, our research aims to expand upon their observations and considerations. It does this by seeking to understand how responses by teachers to citizenship education in primary schools are being made through the policy of using fundamental British values for generating a connection to notions of Britishness and British identity.

\section{Social policies for education on national identity}

Race (2015) provides an in-depth discussion on a range of social policies such as assimilation, integration and multiculturalism, implemented by successive governments to assist with addressing immigration to Britain and the dilemma of teaching about national identity through education. Assimilation is identified as regarding 'diversity as a problem and cultural differences as socially divisive' (Coelho, 1998: 19). Assimilation as a one-way process of social change in Britain meant that minority ethnic immigrant groups were expected to adapt to white British majoritarian cultural norms (Gillborn, 2008; Moncrieffe, 2017).

Integration as a process of adaptation and acculturation required the incorporation of diversity into the mainstream, in order to seek to address the dilemma of national identity through education (Coelho, 1998; Modood, 2007; Race, 2015). 
However, it is suggested by Race (2015) that although integration implies a two-way process with cultural diversity, like assimilation, it is still a one-way process controlled by institutions such as the nation state and government-run offices for education.

Multicultural education policies have aimed to adopt an inclusive approach to ethnic diversity and national identity by having a perspective which understands humans as being culturally embedded and seeing cultural diversity as desirable (Banks and Banks, 2007; Parekh, 2000). However, there have been conflicting views on the outcomes of multiculturalism and its ability to offer true inclusion for all (Tomlinson, 2015; Gillborn, 2008). For example, following the widespread minority ethnic group uprisings in Britain during the early 1980s, where white British institutions such as the government and police were challenged on discrimination and racism (Moncrieffe, 2017, 2018), the emerging policy rhetoric of multiculturalism of Education for All in the Swann Report (1985) is argued to have failed to filter into the consciousness of society and the education system (Gilroy, 1987). It is suggested that 'tokenistic inclusion of Black Studies, Asian Studies and Ethnic Studies' needed to go much further in order to promote more than a harmonious and 'well-integrated' society (Singh in Race, 2015: 9).

\section{Britishness and British identity}

In the wake of a terrorist attack in Britain in July 2005 (more commonly known as 7/7) that was associated with British-born Muslims, Gordon Brown, the then Labour chancellor, spoke of the need to reinforce what he called Britishness, suggesting it would serve as a platform to build stronger social cohesion among British people (Brown, 2006). Critical responses towards Brown's vision of teaching and learning about Britishness are found in Osler's (2009) responses and concerns about the potential reinforcement of an essentialist version of British identity through an unproblematic and Anglocentric lens and narrative, rather than a complex process reflecting on Britain as a community of communities. Maylor (2010) shares a similar view, suggesting that defining a British identity both in policy and schools could lead to problems where teachers' and pupils' understandings of Britishness offer different constructions. Colls (2011: 575) argues that when there are competing definitions of Britishness, it becomes a problematic notion and a slippery subject. Brown's (2006) speech followed on from a government report where it had been stated that communities in Britain were being 'polarised along ethnic, racial or religious lines' (Home Office, 2011: 10). However, research by Heath and Roberts (2008) and Foresight Future Identities (2013) emphasized that no specific minority groups had been identified as not having or ascribing to a British identity. This appears contrary to the political discourse of apparent community and social segregation (Blair, 2006), which suggested that minority ethnic groups were resistant to a sense of British identity and needed to be targeted in relation to their lack of national loyalty (Keddie, 2014: 3).

\section{The emergence of 'fundamental British values'}

Former Prime Minister David Cameron (2010-16) blamed state policies of multiculturalism for failing to shape a common sense of British identity and for causing the rise in extremism and radicalization in Britain (Cameron, 2011). However, it is argued that the perceived lack of a sense of shared British identity has not been due to the failure of multicultural social policies but is rather a result of other social and political factors, including white British majoritarianism and institutional racism (Conversi, 2012; Gillborn, 2008; Kapoor, 2013; Pathak, 2008). Cameron's (2011) speech in which he 
discussed the failure of state multiculturalism should be considered as a significant moment where a notion for teaching and learning about fundamental British values in schools emerged (Race, 2015). He spoke of believing in 'certain values [and a country] that actively promotes them' (Cameron in Race, 2015: 129-30).

The concept of fundamental British values was applied as a definitive educational policy through the Prevent Strategy (2011), with the key aim being to stop young people in education from becoming radicalized and allowing them to develop 'a sense of belonging and support for our core values' (Home Office, 2011: 3.6). The values are taught through spiritual, moral, social and cultural (SMSC) education (DfE, 2014). The document states that schools should promote fundamental British values by 'actively promoting the values ... challenging opinions or behaviours in school that are contrary to fundamental British values' (DfE, 2014: 5). Under David Cameron's coalition government (2010-15) the revised Teachers Standards (2011) included a new section in Part 2 of the document that made it a statutory duty for teachers to uphold fundamental British values. In response to this, Lander (2016: 276) suggested that social contexts and political discourses had been manipulated: 'the preparation of teachers to teach in a culturally diverse society has been preceded by the vilification and ridicule of multiculturalism ... set against the backdrop of the "war on terror".'

Further concern comes from Elton-Chalcraft et al. (2017: 30), who argue that 'the role of the teacher has been conceived and imposed with respect to fundamental British values and counter-terrorism within a vacuum devoid of professional dialogue'. They suggest that an assumption has been made by policymakers that teachers will know how to promote and articulate fundamental British values without seeming to indoctrinate or promote jingoism in schools and classrooms. It is a view that relates to Keddie's (2014) study, where it was found that some teachers' narrow conception of British culture is racialized in its apparent privileging of national identity along the lines of geography/tradition (for example, place of birth, monarchy, pride in British achievements) rather than the values of democracy.

\section{The power of visual discourses}

Foucault (1972) argues that it is important to think about power relations when looking at what is made available through discourse, and this includes the visual. Knowledge is discursive, and a hegemonic discourse will lay claim to a truth, leading to social constructions of difference, authority and social inequality (Rose, 2016). It is suggested that a 'depiction is never just an illustration ... it is the site for the construction and depiction of social difference' (Fyfe and Law, 1998: 1). The concept of cultural reproduction (Bourdieu, 1990) suggests that social disadvantages and inequalities are maintained and furthered through the hidden curriculum transmitting the norms, values and beliefs of the dominant group or culture. According to Hall (1997), discourses encompass different modes of communication practices that systematically construct our knowledge of reality, making it persuasive in creating and reproducing knowledge or truths within a culture or society. Foucault (1972) shows that a discourse can become a regime of truth; that is, a dominant interpretation of phenomena that majority viewpoints are influenced and situated with, to the extent that they champion and preserve the discourse as hegemony and common sense (Gramsci, 1971; Schneider, 2013). Casting this critical gaze on the educational policy around fundamental British values (DfE, 2014) can assist us in examining the extent to which primary schools and teachers by their interaction with political, social and educational discourses may become subjects of those discourses; how they can potentially be disciplined 
into certain ways of thinking and acting, thus potentially reifying the discourse as hegemony (Gramsci, 1971). Where dominant discourses are initially located and fed through socially powerful organizations and institutions, such as the media and government, they can emerge through policy enactment in education and in schools. Primary schools are powerful sites in which dominant discourses applied as commonsense perspectives can be articulated in order to shape how the social world should be understood (Tonkiss, 1998 in Rose, 2016). Foucault's (1972) perspectives discourse is applied in this research through an examination of the power of imagery that is used as representations of national identity on primary school display boards. These perspectives are applied to the monoculturalism and multiculturalism debate.

\section{Methodology}

The research consisted of two stages of data collection and analysis:

1. Stage 1: internet search of primary school display board imagery representing fundamental British values.

2. Stage 2: semi-structured interviews with teachers concerning the imagery used on display boards to represent fundamental British values.

\section{Stage 1: Internet search}

The purpose of the internet search was to observe and to analyse how primary schools communicate discourses on British identity through the imagery that is used on display boards to represent the meaning of fundamental British values. We conceived that identifying and analysing the most widely used images would provide a view of the dominant discourses that are being communicated. Our approach was positioned with Panofsky's (Rose, 2016) theory of iconography, an approach to the examination and analysis of imagery that can provide an interpretation of cultural significance, and where the intrinsic meaning of an image as a statement can reveal underlying principles and attitudes. By focusing on imagery and context to explore interpretative power, we saw our application of iconography as a form of discourse analysis (Rose, 2016).

We used the internet search engine Google Images and applied the search term: 'display boards of fundamental British values'. In our recognition that information is both uploaded and removed from the internet on a daily basis, we carried out our search over the course of one week. We selected 40 display boards from the websites of primary schools in the south-east of England, the Midlands, the north-west of England, London and the north-east of England. Each display board included the title phrase 'British Values' as well as fundamental British values as expressed in words and phrases such as 'democracy', 'the rule of law', 'individual liberty', 'mutual respect' and 'tolerance' of those with different faiths and beliefs (DfE, 2014). Our focus was on visual imagery that was being used to represent these fundamental British values rather than written statements or words used to represent them. We ensured that the images used on each display board selected were clearly visible for examination and analysis, discounting all display boards where the imagery was unclear. Our narrowing of the sample reduced the number of display boards to 27 .

Imagery used on each of the display boards was first categorized as belonging to one of three main groups: national symbols, cultural symbols and cultural icons (Elgenius, 2005; Smith, 2016). Elgenius (2005: 25) argues that national symbols such as flags are physical manifestations that reify 'nation-ness' so that it is visible and tangible. Therefore, the national flags and emblems that appeared in the search 
were categorized as 'national symbols'. Hall (1997: 14) discusses culture as being forged by shared maps of meanings that use symbols to organize and regulate social practices. Symbols representing cultural ceremonies, religion, traditions, rituals and values were grouped as 'cultural symbols'. Then we applied the concept in which history and historical space are used in the formation and maintenance of national identity (Smith, 1993). Cultural artefacts and icons that members of a culture identify with as being representative of that culture, such as monuments, statues, well-known people, buildings and architecture, landscape and the capital city, were categorized as 'cultural icons'.

Next, the frequency of each individual image that was used at least once on a display board was noted. For example, the image of Queen Elizabeth II was used on 18 of the 27 display boards analysed. In taking this approach we applied a degree of subjectivity in deciding what images denoted a cultural symbol or cultural icon. Although this could be criticized as being a subjective bias in our categorization, it was an approach that reflected the relativist perspective by which the research was framed (Cohen et al., 2011).

\section{Stage two: Semi-structured interviews}

The research sought primary school teachers' perceptions of the images that were being used on display boards as visual representations of fundamental British values. This methodological positioning is linked to the phenomenological lens of Schutz $(1962,1967)$, which shows how individual human beings give meaning to their realities. In other words, we examine, analyse and present personal expressions of meanings relating to the imagery that is used to project the phenomenon of fundamental British values.

Three primary school teachers agreed to take part in this research. We chose this sample according to the primary schools we were able to visit. They are known in this research as Teacher A, Teacher B and Teacher $C$.

Teacher $A$ is female and of Afro-Caribbean ethnic origin. She works in an urban multicultural state school (government funded) of approximately 300 children aged 3 to 11. The support staff and teachers at her school are also of broad and diverse multicultural ethnic backgrounds. She was involved in the discussion about the construction of her school's fundamental British values display board. She oversees personal, social, health and economic education (PSHE) for her Year 5 class. Teacher $B$ is female and of White British ethnic origins. She works in a rural private school (non-government funded) of 150-70 children aged 3 to 13. White British is the dominant ethnic background of the children, teachers and support staff. She was not involved in the discussion about or construction of her school's fundamental British values display board. She teaches PSHE to her Year 4 class. Teacher $C$ is female and of a White British ethnic background. She works in a rural state school (government funded) of approximately 120 children aged 3 to 11 . White British is the dominant ethnic background of the children, teachers and support staff at her school. She was involved in the discussion about, but not the construction of, her school's fundamental British values display board. She teaches PSHE to her Year 6 class. All three teachers are aged over 40 .

A uniform approach to questioning was applied through the semi-structured interviews, in which open-ended questions allowed each teacher to talk more freely about their meaning-making. Although standardized wording in the questions may constrain the questions and answers (Patton, 1980), we considered that a uniformity in the patterns of responses would help us to organize and analyse the data. 
Table 1: Images that represent fundamental British values on primary school display boards

\begin{tabular}{|c|c|c|c|c|}
\hline Frequency & Imagery & Category & $\begin{array}{c}\text { Number of display } \\
\text { boards with at } \\
\text { least one of this } \\
\text { image displayed }\end{array}$ & $\begin{array}{l}\text { Percentage } \\
\text { of display } \\
\text { boards using } \\
\text { this image } \\
\end{array}$ \\
\hline $1 \mathrm{st}$ & British union flag & $\begin{array}{l}\text { National } \\
\text { symbol }\end{array}$ & 27 & 100 \\
\hline 2nd & The Queen & Cultural icon & 18 & 67 \\
\hline $3 r d$ & Religious symbols & Cultural symbol & 15 & 56 \\
\hline 4th & Holding/touching hands & Cultural symbol & 13 & 48 \\
\hline$=5$ th & Red Routemaster bus & Cultural icon & 10 & 37 \\
\hline$=5$ th & Winston Churchill & Cultural icon & 10 & 37 \\
\hline$=7$ th & Queen's Guard & Cultural icon & 9 & 33 \\
\hline$=7$ th & The poppy & Cultural symbol & 9 & 33 \\
\hline$=7$ th & Houses of Parliament & Cultural icon & 9 & 33 \\
\hline 10th & Red telephone box & Cultural icon & 7 & 26 \\
\hline 11th & Cup of tea/teapot & Cultural symbol & 5 & 19 \\
\hline$=12$ th & Tower Bridge & Cultural icon & 4 & 15 \\
\hline$=12 \mathrm{th}$ & Fish and chips & Cultural symbol & 4 & 15 \\
\hline$=12$ th & Scales of Justice & Cultural symbol & 4 & 15 \\
\hline$=12 \mathrm{th}$ & $\begin{array}{l}\text { Other members of the } \\
\text { royal family }\end{array}$ & Cultural icon & 4 & 15 \\
\hline$=12$ th & $\begin{array}{l}\text { Cricket/Football/ } \\
\text { Wimbledon tennis }\end{array}$ & Cultural symbol & 4 & 15 \\
\hline$=17$ th & David Cameron & Cultural icon & 3 & 11 \\
\hline$=17 \mathrm{th}$ & NHS/Firefighter & Cultural symbol & 3 & 11 \\
\hline$=17$ th & Policeman/woman & Cultural symbol & 3 & 11 \\
\hline$=20$ th & William Shakespeare & Cultural icon & 2 & 7 \\
\hline$=20$ th & London Eye & Cultural icon & 2 & 7 \\
\hline$=20$ th & Stonehenge & Cultural icon & 2 & 7 \\
\hline$=20$ th & Red pillar post box & Cultural icon & 2 & 7 \\
\hline 24th & Others* & Mixture & 1 & 4 \\
\hline
\end{tabular}

* Images that appeared on one display board only: St George, bulldog, Paddington Bear, Mo Farah, The Beatles, ballot box, judge, shamrock, daffodil, London Underground sign, Nelson Mandela, bowler hat, Theresa May, Harry Potter, Jason Kenny (British cyclist).

The 27 fundamental British values display boards used in the research were numbered 1 to 27 , and through the use of an online random number selector, five were selected. These were used as stimuli for the semi-structured interviews, with the teachers being asked about the meanings they made from the images on these five display boards.

We applied a method of thematic coding to the data that emerged from the teachers' responses. Coding of themes allowed us to focus on significant phrases and individual words that related to notions of British values in relation to British identity. We were open to these responses and coded the themes both deductively and inductively. We recognized a pattern in the discussion of multiculturalism that was indicative of developing a national identity framed by a sense of belonging and cohesion among ethnically diverse national citizens (Parekh, 2008; Race, 2015), and we applied the code 'MULTI-CULT' in relation to the data. We also recognized a pattern when we discussed how the teachers expressed notions of assimilation to a dominant 
discourse of British identity and monoculturalism, and as a signifier of this we applied the code 'MONO-CULT'. Data emerging from the teachers' responses that indicated hegemonic cultural reproduction were marked by the code 'CULT REPRO'. We also saw data in the teachers' responses that related to the construction of a shared sense of nationalism and British identity based on civic values and on ethnic values respectively (Heath and Roberts, 2008; Ignatieff, 1993; Smith, 1993), and the codes 'CIVIC NAT' and 'ETHNIC NAT' were applied in relation to this. Data emerging from the teachers' responses that were indicative of minority ethnic groups being 'othered' by imagery representation were marked by the code 'OTHER'.

\section{Findings}

In presenting our examination and analysis of the data, we focused on the apparent trends emerging from our coding and categorization of imagery used on primary school display boards. Following on from this, we blended our presentation and analysis of data from the semi-structured interviews with a discussion of the key themes that emerged from our processes of coding and categorizing.

Table 1 shows the frequency of images used in order to represent fundamental British values on primary school display boards.

\section{Ethnic nationalism}

More than 50 per cent of the images from the 27 display boards were classified as cultural icons (Elgenius, 2005; Smith, 2016); for example Queen Elizabeth II, Routemaster bus, former Prime Minister Winston Churchill, the Queen's Guard, the Houses of Parliament, a red telephone box, a cup of tea, Tower Bridge, William Shakespeare and a red post box. Of the cultural symbols, the image of holding hands was the most commonly found, on almost 50 per cent of the display boards, followed by religious symbols. Cultural symbols such as the red poppy were seen on over 30 per cent of the display boards. Other cultural symbols such as a cup of tea, fish and chips, and representations of sports such as tennis, football and cricket were identified on between 15 and 20 per cent of the display boards. Significantly, over 80 per cent of the 27 display boards that used cultural icons and symbols presented ethnocentric white British identities and histories to represent notions of fundamental British values.

When a random selection of the display boards was put to the teachers, they responded that the images used were unrepresentative of the stated fundamental British values (DfE, 2014). Rather, they were more representative of what they considered to be dominant and stereotypical cultural and ethnic images of England relating to a tourist's view of London:

They represent what you see if you went to London if you went to Buckingham Palace and then see the guards ... black cabs in London ... Tower Bridge is in London ... well they represent London from a tourist perspective almost if you went into a tourist gift shop these are the stereotypical images of London. (Teacher A responding to Display Board 2; see Figure 1)

Illustration of a soldier, red bus, cricketer, Winston Churchill in profile, the royal crown, one more picture of the Queen, then a picture of a soldier and a bus, a London taxi, so British values with those sort of images, I'm not 
sure it says anything about values, it's really typical English things that you would see and associate with Britain. (Teacher B responding to Display Board 17; see Figure 2)

Like Winston Churchill, historical things, you might say that are not necessarily values of today. (Teacher $C$ responding to Display Board 17; see Figure 2)

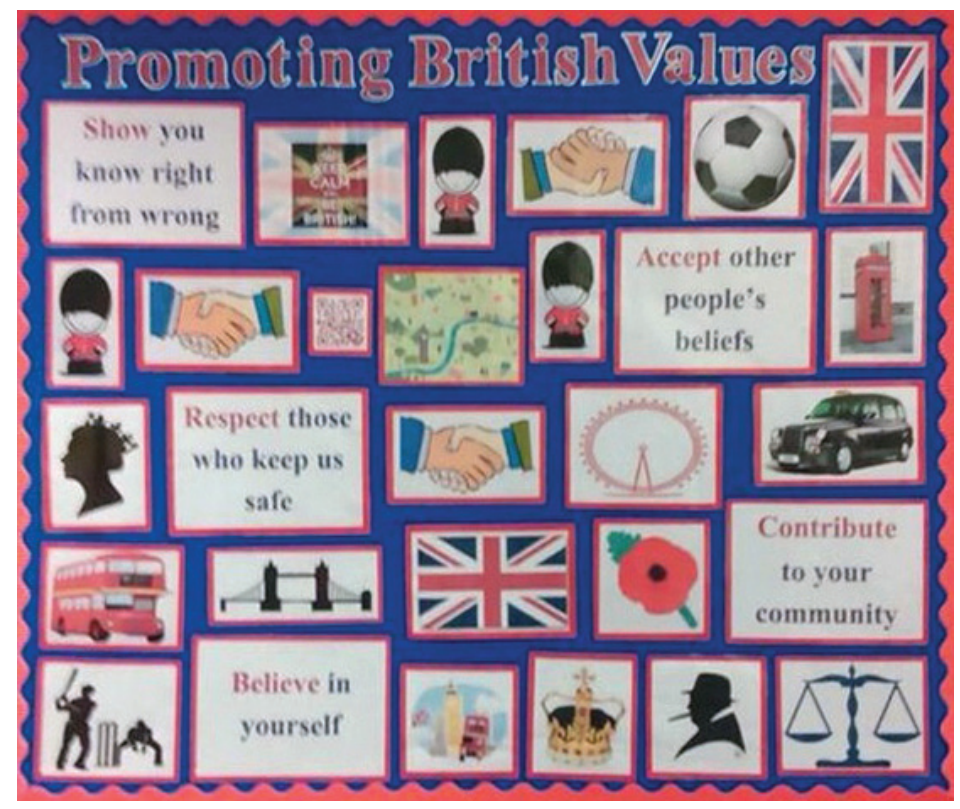

Figure 1: Display Board 2

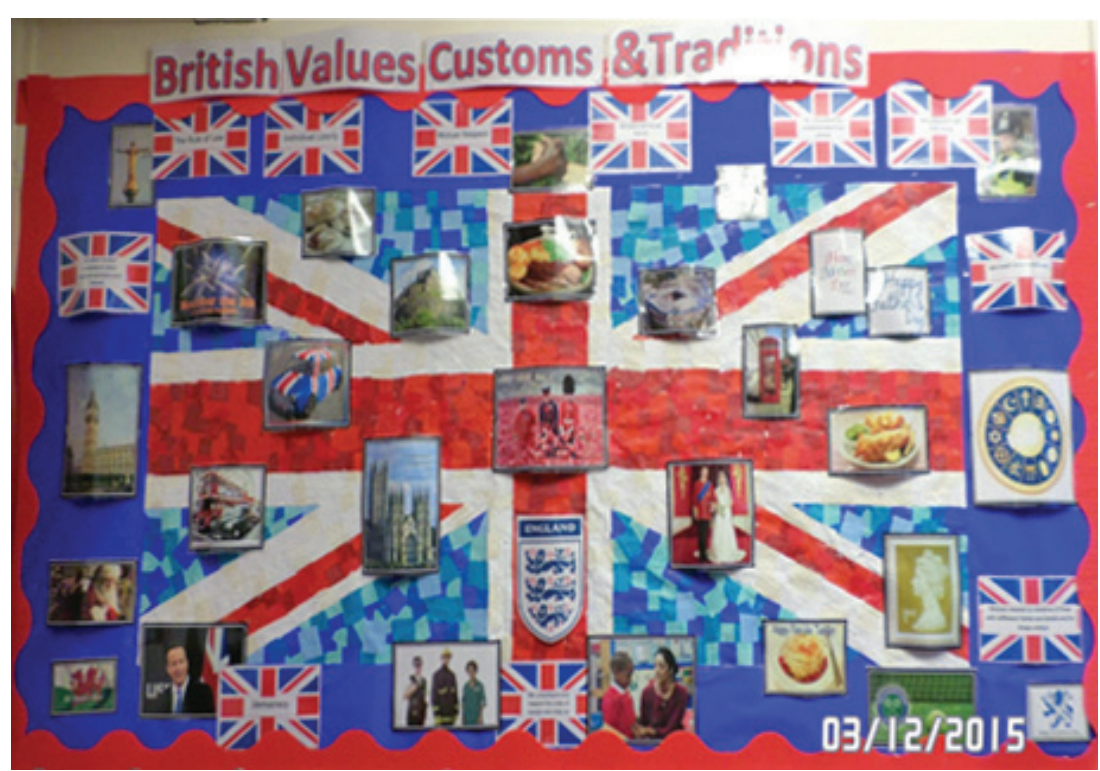

Figure 2: Display Board 17

A national identity framed by ethnic nationalism is spoken of as being exclusive and backward looking, and using ethnic criteria to emphasize pride in Britain's history (Heath and Roberts, 2008). Teacher A also comments on the images from Display 
Board 17, seeing them as cultural symbols of British elitism and power linked to an imperial past, and being reinforced in the present by the display boards:

Cricket as a sport is played in countries who were part of the British Empire, the crown there as well, this display board, it almost to a certain extent reminds me of a UKIP statement, things that they want to be maintained ... but has nothing to do with these words and British values ... more to do with a statement of power, what is seen as culture and history. (Teacher A responding to Display Board 17)

These interpretations position Display Board 17 as aiming to represent British values through images related to historic British cultural imperialism, which then act as more of a guide to knowing about British identity today, whilst maintaining its historic form.

\section{Monocultural representations of 'whiteness'}

The teachers' responses indicated their view about the dominance of white British people in imagery that represents fundamental British values. Teacher A sees the images as symbolizing power and elitism rather than being associated with fundamental British values:

Powerful icons of Britishness, the Queen, Churchill, they are symbols of power and elitism and easily recognizable by people around the world really. (Teacher A responding to Display Board 7; see Figure 3)

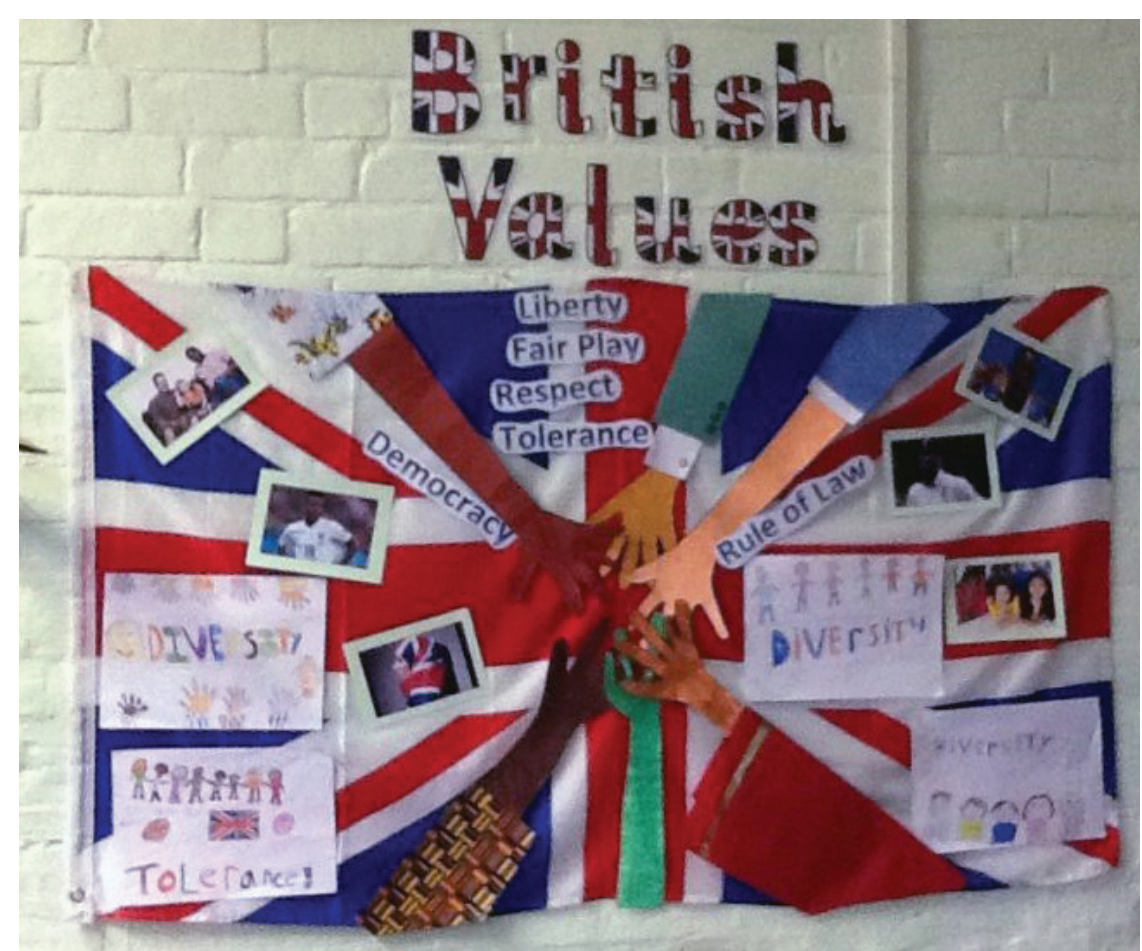

Figure 3: Display Board 7

On the 27 display boards, almost all images of cultural (British) icons are white British people in positions of privilege and power: Queen Elizabeth II, former prime ministers Winston Churchill and David Cameron, Prime Minister Theresa May, national playwright 
William Shakespeare and the Queen's Guard. There were just two identifiable nonwhite exceptions: one image of Olympic athlete Sir Mo Farah, and one post-apartheid image of former South African President Nelson Mandela. Imagery of law enforcers such as the white policeman and white policewoman and a white male judge, framed together on the display boards with images of white British cultural icons such as Queen Elizabeth II and three prime ministers, appear to impose the sense of a dominant white British monocultural power-base and perspective for the meaning of British culture and identity. Teacher $C$ noted images of white policemen and women on the display boards, and articulated the need for a more ethnically diverse representation: 'Yeah more police presence, different coloured policemen' (Teacher $\mathrm{C}$ responding to display boards).

Conversi (2012) suggests that a monocultural national identity is produced through assimilation to a dominant and exclusive narrative of British identity, where the practice of ethnic discrimination suppresses and 'others' minority presence (Mann, 2004). Where dominant representations of cultural symbols and icons are of a white British monoculture, the theoretical lens of 'Whiteness' can be applied to explain the hegemonic functions of fundamental British values display boards. Frankenberg (1993: 526) writes: 'Whiteness signals the production and reproduction of dominance rather than subordination; normativity rather than marginality, and privilege rather than disadvantage.' 'Whiteness' as power and authority is reinforced by the dominance of white British identities on these display boards.

\section{Othering}

Stokes and Gabriel (2010) describe the process of casting a group into the role of the 'other' and establishing one's own identity through opposition to and (frequently) vilification of this 'other'. A sense of this emerged in the teachers' responses:

There is a black hand in the top in the middle, but I don't know what it's actually doing, black boy and Asian adult, not sure what British values they are supposed to represent. I don't know how much children will get out of this one except for maybe reinforcing stereotypes of minority ethnic people in Britain. (Teacher A responding to Display Board 7)

It seems to be more multicultural with the images of a black football player. But that particular image doesn't really represent the words of tolerance, equality and respect. I mean, it's just a football player who happens to be black. (Teacher A responding to Display Board 11; see Figure 4)

Teacher A observes that the images of minority ethnic people have no clearly identifiable purpose on the display boards in relation to fundamental British values. In contrast, images of white people are shown in positions of law enforcement and authority to indicate the fundamental British value 'rule of law' (DfE, 2014). This positions minority ethnic people as the impotent 'other' and relates to what Singh (1993 in Race, 2015) argues is a tokenistic representation of minority ethnic groups. 


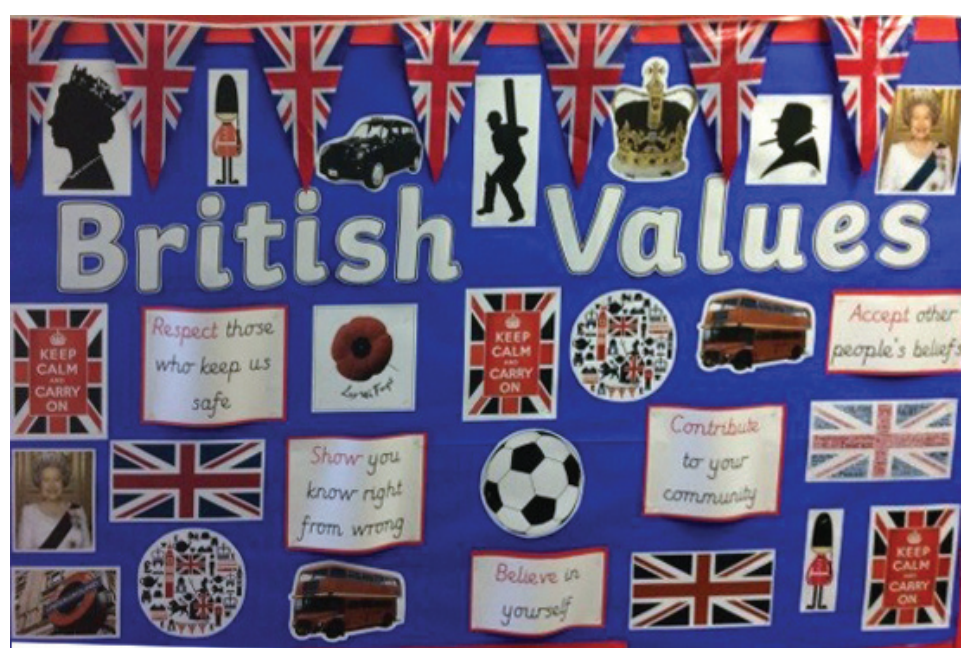

Figure 4: Display Board 11

\section{Assimilation}

Teacher $C$ discusses the need for assimilation to and acceptance of dominant forms of British history, culture and society by those coming to live in Britain:

Winston Churchill put him on ... on number 11, black silhouette of the Queen, they are part of the system and what you accept if you come to live here, and they are in the past anyway, so they are part of the history side of things. (Teacher $\mathrm{C}$ responding to Display Board 11)

Teacher $C$ also supports the idea that fundamental British values are necessary for a formation of a cohesive sense of British identity:

It goes deeper than this, this is just the poster, but you've got to learn what it's like to really come up against somebody else's belief and when it doesn't really acknowledge British values and how are we going to deal with it? You've got to first of all know what the British values are. (Teacher $\mathrm{C}$ responding to Display Board 11)

These statements highlight the concerns of Elton-Chalcraft et al. (2017: 31): the 'assumption that the shared values of Britishness are synonymous with a strong society and that society is weaker where different values exist'. Teacher $C$ suggests that teaching and learning about fundamental British values will bring about a sense of belonging and connection to a British identity among the 'other' through their assimilation into a dominant British culture. Teacher C's comments relate to Coelho's (1998) argument that assimilation regards diversity as a problem and cultural differences as socially divisive.

\section{Multicultural British identity}

In the teachers' responses, they denote multiculturalism as an inclusive part of British identity:

I like the idea of different faces representing multiculturalism and diversity as it gives a sense of pluralism there... that's much more inclusive than the others. (Teacher A responding to Display Board 11) 
It looks like children's hands reaching into the middle altogether in a sort of image of unity. (Teacher B responding to Display Board 11)

I like the children of mixed race on the bus ... you do need everybody pulling together. (Teacher $C$ responding to Display Board 25; see Figure 5)

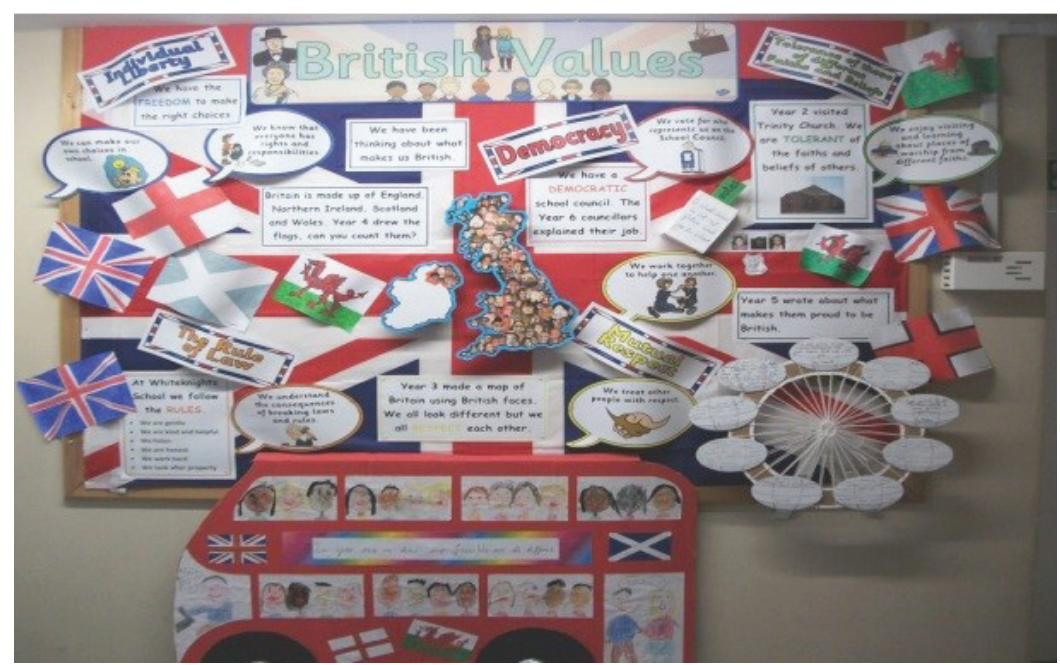

Figure 5: Display Board 25

The concept of multiculturalism was also observed by all the teachers when they interpreted Display Board 11, representing the fundamental British values of 'mutual respect', 'tolerance' and 'individual liberty' (DfE, 2014):

Maybe it's more of an overarching word for tolerance, respect. (Teacher A)

Children's pictures depicting diversity and tolerance with holding hands.

(Teacher B)

You mustn't get rid of their individuality. (Teacher C)

Their responses refer to multiculturalism in relation to national identity as a form of inclusivity that is built predominantly on civic values. Their views relate to theories of multiculturalism discussed by both Banks and Banks (2007) and Parekh (2000) that understand humans as being culturally embedded.

\section{Civic nationalism}

A pattern in the teachers' responses emerged that denotes a sense of civic nationalism being articulated as British identity. In their discussion of Display Board 11, the teachers were in agreement that the image of holding hands that meet on top of a union flag was the most successful in representing most of the key terms that relate to fundamental British values (DfE, 2014), sharing a cohesive sense of connection and belonging to British identity:

With those hands in the middle that touch in the centre of the flag represents a form of humanism and diversity that I guess those words respect, tolerance, democracy all symbolize. (Teacher A) 
This one is very good on mutual respect, the image of the hands joining in the middle er ... I like this one because it's the coming together. (Teacher B)

Because that says more, every colour hand ... so if you are wanting to talk about British values in that one, that's the one that says most things, democracy, fairness, individual liberty and tolerance, mutual tolerance ... I think that's a good one. (Teacher C)

Heath and Roberts (2008) discuss a primarily civic national pride as one that is achieved through Britain's welfare state and political institutions. This is reflected in the teachers' comments in which they place great significance on the images of the police, firefighters and the National Health Service (NHS) on Display Board 7 in terms of fundamental British values and British identity:

The image of the policewoman, the firefighter and the NHS represents institutions that we as tax payers pay into to support and maintain the nation, so I would definitely keep that one. (Teacher A)

Workers who sort of safeguard the country and the people ... policewoman, fireman, nurse. (Teacher B)

Policeman, firefighter, that's good, showing caring jobs and different races, maybe make that more obvious by blowing it up. (Teacher $\mathrm{C}$ )

All three teachers identified on Display Board 7 the religious symbols that were applied to represent the fundamental British value of 'mutual respect and tolerance of those of different faiths' (DfE, 2014). It was also suggested that there needed to be more images to show diverse representations of religion in Britain, emphasizing the pluralistic nature of British identity:

It doesn't fully reflect British society. There's no image of a Sikh temple or a Muslim place of worship or a picture of the Quran so there's very little of that. (Teacher A)

I can't see any Muslims on this one or different faiths or on the previous one. (Teacher C)

Across the 27 display boards, images of religious symbols and holding hands were the third and fourth most frequent images, appearing alongside images of the scales of justice ( $=12$ th) and the police (=17th). These images construct a shared British identity that is based on civic values (Ignatieff, 1993), which Heath and Roberts (2008: 3) suggest is more inclusive. Countries that have stronger civic conceptions also exhibit high levels of good citizenship.

\section{Discussion}

Our examination and analysis of data shows teachers producing a mixture of shared and different responses in their interpretations of fundamental British values that construct a sense of British identity. The responses of Teacher $A$ to the images of fundamental British values display boards suggest an alignment with understanding British identity through the discourses of multiculturalism, pluralism and cultural diversity (Race, 2015). This relates to the use of civic values in order to construct a British identity. Teacher A raised concerns about the dominant white British images that are used on display boards and their potential to shape the exclusion of minority ethnic groups. Teacher B's responses relate to notions of civic values for 
the construction of a British identity (Ignatieff, 1993), but are also indicative of ethnic values. Teacher $B$ represents the hybrid nature of British identity that Heath and Roberts (2008) discuss as the most common form, based on both civic and ethnic values, and this highlights a possible tension with the principally civic nature of fundamental British values. Teacher C, like Teacher B, seemed to acknowledge both ethnic and civic values in knowing British identity, but was predominantly concerned with the importance of ethnic values (Ignatieff, 1993). Teacher $C$ produced responses in relation to the notions of 'othering' and 'assimilation', and these can be associated with ethnic nationalism (Ignatieff, 1993; Race, 2015).

In responding to the interview questions about which of the display boards they felt most and least represented fundamental British values, all three teachers agreed that Display Board 11 was most representative. All images on this display board were interpreted by the teachers as being inclusive, multicultural and representing a diverse sense of shared British identity. The image of holding hands that touch in the middle of the British union flag was interpreted as representing unity and the fundamental British values of 'individual liberty' and 'mutual respect and tolerance' (DfE, 2014). All the teachers articulated words and phrases aligned closely to the notion of civic nationalism. Interestingly, the cultural symbol of holding hands was the third most dominant image on the 27 display boards. Display Board 11 does not display any images of white cultural icons, such as Queen Elizabeth II, Winston Churchill and Shakespeare; neither does it display cultural icons and cultural symbols related to the City of London or traditional 'English' celebrations and foods. All three teachers agreed that Display Board 17 was least representative of British identity, as they did not identify any of the images as being representative of fundamental British values. The teachers interpreted the images as being stereotypical representations of England, or more specifically of London. Significantly, examples of these images from Display Board 17 are found on over 80 per cent of the 27 display boards showing fundamental British values that were analysed in this research, and are drawn from the following: Queen Elizabeth II, cricket/football, Queen's Guard, red Routemaster bus, Winston Churchill, the red poppy, 'Keep Calm and Carry On' poster and a black taxi cab. The teachers' responses to these images link with the cultural reproduction of whiteness through monoculturalism. They invoke notions of ethnic nationalism as the concept by which a powerful discourse of British identity can be transmitted under the guise of fundamental British values.

\section{Concluding comments}

This study has foregrounded its aims to provide an opportunity for teachers to reflect on images of icons and symbols used on primary school display boards of fundamental British values in order to represent British identity. When given this opportunity, teachers interpreted most of the dominant images of common icons and symbols of traditional British culture as not representing fundamental British values. The display board chosen by all teachers as being least representative used images that were icons and symbols of an ethnocentric traditional and stereotypical white British culture. Our research has identified that primary school fundamental British values display boards imagery generally project dominant white British majoritarian perspectives and discourses of British identity (Conversi, 2012; Pathak, 2008). We suggest that the continued uncritical use and endorsement of such images to represent fundamental British values by teachers serves to maintain the power of exclusive monocultural white British identities and perspectives, upheld as the norm, 
to the general exclusion of minority ethnic British identities and perspectives. In this way, a 'regime of truth' (Foucault, 1972) for knowing about Britishness and British identity through a white British perspective is maintained. Our research suggests that the Prevent Strategy (Home Office, 2011) in its policy directives on the teaching and learning of fundamental British values has served to produce responses by schools that validate and spread 'whiteness' as power, dominance, normativity and privilege (Frankenberg, 1993). Arguably, it is a policy that, by its uncritical enactment, can be referred to as what Gillborn (2008: 4) describes as a 'business as usual' form of racism.

\section{Notes on the contributors}

Marlon Moncrieffe, formerly a primary school assistant head teacher, is a senior lecturer at the School of Education, University of Brighton. His research interests focus on using twentieth-century Black British history in teacher education, and in classroom teaching and learning about British values and British identity.

Audrey Moncrieffe is a primary school teacher with over 20 years of teaching experience in urban and rural primary schools, with both dominant multicultural and dominant monocultural backdrops.

\section{References}

Banks, J.A. and McGee Banks, C.A. (eds) (2007) Multicultural Education: Issues and perspectives. 6th ed. Hoboken, NJ: Wiley.

Berger, P.L. and Luckmann, T. (1966) The Social Construction of Reality: A treatise in the sociology of knowledge. Garden City, NY: Anchor Books.

Blair, T. (2006) 'The duty to integrate: Shared British values'. Lecture series: 'Our nation's future'. Speech given on 8 December 2006. Online. http://webarchive.nationalarchives.gov. uk/20080909022722/http://www.number10.gov.uk/Page10563 (accessed 1 September 2015).

Bourdieu, P. (1990). In Other Words: Essays towards a reflexive sociology. Stanford, CA: Stanford University Press.

Brown, G. (2006) 'Who do we want to be? The future of Britishness'. Speech given to the Fabian Society, 16 January 2006. Online. http://fabians.org.uk/events/new-year-conference-06/brownbritishness/speech (accessed 15 January 2016).

Cameron, D. (2011) 'PM's speech at Munich Security Conference'. Online. https://tinyurl.com/ ydg4ld9f (accessed 18 November 2018).

Cantle, T. (2001) Community Cohesion: A report of the Independent Review Team. London: Home Office.

Casey, D. (2004) 'Challenges of collecting data in the clinical setting'. Nursing Times Research, 9 (2), 131-41.

Coelho, E. (1998) Teaching and Learning in Multicultural Schools: An integrated approach. Clevedon: Multilingual Matters.

Cohen, L., Manion, L. and Morrison, K. (2011) Research Methods in Education. 7th ed. London: Routledge.

Colls, R. (2011) 'The lion and the eunuch: National identity and the British genius'. Political Quarterly, 82 (4), 574-95.

Conversi, D. (2012) 'Irresponsible radicalisation: Diasporas, globalisation and long-distance nationalism in the digital age'. Journal of Ethnic and Migration Studies, 38 (9), 1357-79.

Crick, B. (2008) 'Citizenship, diversity and national identity'. London Review of Education, 6 (1), 31-7.

Denscombe, M. (2014) The Good Research Guide: For small-scale research projects. 5th ed. Maidenhead: Open University Press.

DfE (Department for Education) (2011) Teachers' Standards: Guidance for school leaders, school staff and governing bodies. London: Department for Education. Online. https://tinyurl.com/ yc48qlrp (accessed 18 November 2018).

DfE (Department for Education) (2014) Promoting Fundamental British Values as Part of SMSC in Schools: Department advice for maintained schools. London: Department for Education. 
Elgenius, G. (2005) 'Expressions of Nationhood: National symbols and ceremonies in contemporary Europe'. Unpublished PhD thesis, London School of Economics and Political Science.

Elton-Chalcraft, S., Lander, V., Revell, L., Warner, D. and Whitworth, L. (2017) 'To promote, or not to promote fundamental British values?: Teachers' standards, diversity and teacher education'. British Educational Research Journal, 43 (1), 29-48.

Foresight Future Identities (2013) Executive Summary. The Government Office for Science, London. https://assets.publishing.service.gov.uk/government/uploads/system/uploads/ attachment_data/file/273968/13-524-future-identities-changing-identities-summary.pdf (accessed 17 December 2018).

Foucault, M. (1972) The Archaeology of Knowledge. Trans. Sheridan Smith, A.M. London: Tavistock Publications.

Foucault, M. (1980) Power/Knowledge: Selected interviews and other writings, 1972-1977. Ed. Gordon, C. New York: Pantheon Books.

Frankenberg, R. (1993) White Women, Race Matters: The social construction of whiteness. London: Routledge.

Fyfe, G. and Law, J. (1998) 'Introduction: On the invisibility of the visible'. In Fyfe, G. and Law, J. (eds) Picturing Power: Visual depiction and social relations. London: Routledge, 1-14.

Gillborn, D. (2008) Racism and Education: Coincidence or conspiracy? London: Routledge.

Gilroy, P. (1987) "There Ain't No Black in the Union Jack": The cultural politics of race and nation. London: Hutchinson.

Government Office for Science (2013) Future Identities: Changing identities in the UK: The next 10 years: Final project report. London: Government Office for Science. Online. https://tinyurl. com/ycsqn62q (accessed 18 November 2018).

Gramsci, A. (1971) Selections from the Prison Notebooks of Antonio Gramsci. Ed. and trans. Hoare, Q. and Nowell Smith, G. London: Lawrence and Wishart.

Hall, S. (1997) 'The spectacle of the "other"'. In Hall, S. (ed.) Representation: Cultural representations and signifying practices. London: SAGE Publications, 223-90.

Hammersley, M. and Traianou, A. (2012) Ethics and Educational Research. London: British Educational Research Association . Online. https://tinyurl.com/y8o5sr9m (accessed 18 November 2018).

Heath, A. and Roberts, J. (2008) 'British identity: Its sources and possible implications for civic attitudes and behaviour'. Lord Goldsmith's Citizenship Review.

Higgins, C. (2014) 'Grayson Perry's latest tapestry celebrates mongrel Britain'. The Guardian, 21 October. Online. https://tinyurl.com/o33ahkd (accessed 18 November 2018).

Home Office (2011) 'Prevent Strategy 2011'. Online. https://assets.publishing.service.gov.uk/ government/uploads/system/uploads/attachment_data/file/97976/prevent-strategy-review.pdf (accessed 8 December 2015).

Ignatieff, M. (1993) Blood and Belonging: Journeys into the new nationalism. New York: Farrar, Straus and Giroux.

Kapoor, N. (2013) 'The advancement of racial neoliberalism in Britain'. Ethnic and Racial Studies, 36 (6), 1028-46.

Keddie, A. (2014) 'The politics of Britishness: Multiculturalism, schooling and social cohesion'. British Educational Research Journal, 40 (3), 539-54.

Lander, V. (2016) 'Introduction to fundamental British values'. Journal of Education for Teaching, 42 (3), 274-9.

Mann, M. (2005) The Dark-Side of Democracy: Explaining ethnic cleansing. Cambridge: Cambridge University Press.

Maylor, U. (2010) 'Notions of diversity, British identities and citizenship belonging'. Race Ethnicity and Education, 13 (2), 233-52.

Modood, T. (2007) Multiculturalism: A civic idea. Cambridge: Polity Press.

Moncrieffe, M. (2017) 'Examining Experiences and Perceptions of Mass Migration and Settlement in Britain over the Ages: How can this assist teaching and learning in Key Stage 2 history?'. Unpublished EdD thesis, University of Reading.

Moncrieffe, M. (2018) 'Teaching and learning about cross-cultural encounters over the ages through the story of Britain's migrant past'. In Race R. (ed.) Advancing Multicultural Dialogues in Education. Cham: Palgrave Macmillan, 195-214.

Osler, A. (2008) 'Citizenship education and the Ajegbo report: Re-imagining a cosmopolitan nation'. London Review of Education, 6 (1), 11-25.

Osler, A. (2009) 'Patriotism, multiculturalism and belonging: Political discourse and the teaching of history'. Educational Review, 61 (1), 85-100. 
Parekh, B. (2000) Rethinking Multiculturalism: Cultural diversity and political theory. Cambridge, MA: Harvard University Press.

Pathak, P. (2008) The Future of Multicultural Britain: Confronting the progressive dilemma. Edinburgh: Edinburgh University Press.

Patton, M.Q. (1980) Qualitative Evaluation Methods. Beverly Hills, CA: SAGE Publications.

Race, R. (2015) Multiculturalism and Education. 2nd ed. London: Bloomsbury Academic.

Rose, G. (2016) Visual Methodologies: An introduction to researching with visual materials. 4th ed. London: SAGE Publications.

Schneider, F. (2013) 'How to do a discourse analysis'. PoliticsEastAsia, 13 May. Online. https://tinyurl. com/jnmjoj5 (accessed 18 November 2018).

Schutz, A. (1962) Collected Papers: Volume 1: The problem of social reality. The Hague: Martinus Nijhoff.

Schutz, A. (1967) The Phenomenology of the Social World. Trans. Walsh, G. and Lehnert, F. Evanston, IL: Northwestern University Press.

Smith, A.D. (1993) National Identity. Reno: University of Nevada Press.

Smith, H.J. (2016) 'Britishness as racist nativism: A case of the unnamed "other"'. Journal of Education for Teaching, 42 (3), 298-313.

Starkey, H. (2008) 'Diversity and citizenship in the curriculum'. London Review of Education, $6(1), 5-10$.

Stokes, P. and Gabriel, Y. (2010) 'Engaging with genocide: The challenge for organization and management studies'. Organization, 17 (4), 461-80.

Swann, M. (1985) Education for All: The report of the Committee of Inquiry into the Education of Children from Ethnic Minority Groups. London: Her Majesty's Stationery Office.

Tomlinson, S. (2015) 'The empire disintegrates'. Ethnic and Racial Studies, 38 (13), 2208-15.

Wacquant, L.J.D. (1989) 'Towards a reflexive sociology: A workshop with Pierre Bourdieu'. Sociological Theory, 7 (1), $26-63$. 